\title{
Jamie Savan
}

\section{Revoicing a 'choice eunuch': the cornett and historical models of vocality}

They have the ordinary wind instruments in the Quires, as the cornet, sackbut, double curtaile and others, which supply the want of voices, very notorious there; and nothing can so well reconcile the upper parts of a Quire, since we can have none but boys and those none of the best, as the cornet (being well sounded) doth; one might mistake it for a choice eunuch. ${ }^{1}$

Roger North's colourful description (1676) of the use of wind instruments in the cathedral churches of York and Durham is one of many historical sources that allude to the cornett's affinity with the human voice. Yet his evocation of a now-obsolete voice type here neatly encapsulates some of the many issues and problems faced by the instrumentalist seeking to recreate a style of performance based on documented historical practice, rather than simply imitating the singers of our own time. What might a deeper investigation into the relationship between cornett and voice reveal about lost instrumental and vocal practices of the sixteenth and seventeenth centuries? Drawing on sources from a wide geographical area including England, the Italian peninsula and German-speaking lands, this article presents a thematic overview of the symbiosis of instrument and voice, offering new insights into this relationship from a practitioner's perspective.

In spite of the profound political, cultural and religious changes encountered during a chronological span of nearly two hundred years, the careers of cornett makers and players themselves provide important threads of continuity. For example, when members of the Bassano dynasty left Venice for the court of Henry VIII in the 1530s, they established an Anglo-Venetian axis for trading in musical instruments that played a large part in setting standards for the design and manufacture of cornetts and other wind instruments that lasted well into the 17 th century. ${ }^{2}$ The best cornett players were highly sought after during this

\footnotetext{
${ }^{1}$ Cited in J. Wilson (ed.), Roger North on music: being a selection from his essays written during the years c.1695-1728 (London, 1959), p.40. According to $\mathrm{n} .17$ this passage was revised prior to publication as The life of the right honourable Francis North, Baron of Guildford (London, 1742) as follows: 'In these churches, wind musick was used in the Choir; which I apprehend might be introduced at first for want of voices, if not of organs; but, as I hear, they are now disused. To say the truth, nothing comes so near, or rather imitates so much, an excellent voice, as a cornet pipe; but the labour of the lips is too great, and it is seldom well sounded.'

${ }^{2}$ D. Lasocki, The Bassanos: Venetian musicians and instrument makers in England, 1531-1665 (Aldershot: Ashgate, 1995); and specifically on the international trade in musical instruments see D. Lasocki, 'The AngloVenetian Bassano family as instrument makers and repairers', The Galpin Society Journal, xxxviii (1985), pp.112-132, and B. de Pascual, 'Bassano instruments in Spain?', The Galpin Society Journal, xl (1987), pp.745.
} 
period and some enjoyed a high degree of professional mobility, with notable exchanges of players north and south of the Alps, and between England and mainland Europe. Augustein Schubinger, one of the first known exponents of the instrument, enjoyed a truly international career which took him from his home in Augsburg to the courts of northern Italy, the Imperial courts of Innsbruck and Vienna, and, through networks of Hapsburg patronage, to Burgundy and Spain. ${ }^{3}$

\section{Augustein Schubinger and the emergence of the cornett}

Among Hans Burgkmair's woodcuts for the Triumph of Maximilian series (first printed in 1526), we find an important early illustration of a cornettist and trombonist performing within a vocal ensemble (Illus.1). Although the musicians are depicted in fantastical triumphal carts in the tow of an improbably exotic menagerie, the woodcuts include useful evidence of performing practice and contemporary attitudes to music and musical instruments. The cart in question is adorned by a secondary group of musicians in the form of Apollo and the Muses, who serve to introduce and frame some of the central themes of the relationship between instruments and the human voice in the Renaissance. Clio, the Muse of History, is raised above her eight sisters and looks up at the scene as if to emphasise the historical import of this moment. For here we have a pair of wind players elevated to the superior position and status of singers, the significance of which would not have been lost on the classically educated observer. Apollo was well known for keeping ambitious wind players in their place, as played out through the terrible punishment he exacted on aulos-blowing Marsyas. The observer may also have known something of Greek music theory (as transmitted by Boethius), according to which the human voice was itself a musical instrument and the archetype for the 'inanimate' instruments made by man. ${ }^{4}$ Inanimate instruments were, in comparison to the animate voice, deficient, although by the 16th century the notion of imitation (mimesis) provided a means of at least partially mitigating these deficiencies. In this context it is interesting to note that Sebastian Virdung wrote in Musica getutscht (1511) that the instruments of his own day had reached a level of perfection that the ancients could not

\footnotetext{
${ }^{3}$ K. Polk, 'Augustein Schubinger and the zinck: innovation in performance practice', Historic Brass Society Journal, i (1989), pp.83-93.

${ }^{4}$ For a useful overview of Greek taxonomies of musical instruments and their transmission in medieval Europe see M. J. Kartomi, On concepts and classifications of musical instruments (Chicago, 1990), pp.108-21 and pp.135-61.
} 
have imagined and that he did not believe could be surpassed. ${ }^{5}$ The presence of cornett and trombone players among the choir in Burgkmair's woodcut can perhaps thus be seen as a redemption of Marsyas through the ingenuity of Renaissance musical instrument design. [insert illus.1 near here, half page]

In contrast to the fantastical and mythological aspects, the human musicians are depicted almost in hyper-realism; indeed, they purportedly represent the likenesses of named individuals in Kaiser Maximilian's Hofkapelle. Maximilian (1459-1519) had dictated detailed instructions for the composition of the Triumph in 1512, requesting that this cart would carry the singers of his Hofkapelle together with 'Augustin' [Augustein Schubinger] as leader of the cornetts and 'Stewdl' [Hans Steudlin] as leader of the trombones. ${ }^{6}$ Maximilian's instructions suggest that the two named players may have been intended to represent a larger instrumental group, and there may have been an element of artistic licence in the woodcut; nevertheless, the image concurs with numerous documented performances in the early sixteenth century which seem typically to have involved just one or two instrumentalists, usually a cornett and/or a trombone (or possibly a slide trumpet). ${ }^{7}$ The earliest archival references to this kind of activity are found at the turn of the sixteenth century. In 1501, for instance, Augustein Schubinger was named as the player of the cornett at a High Mass in Mechelen, during which time he seems to have been 'on loan' to Maximilian's son, Philip the Fair, Duke of Burgundy. ${ }^{8}$ The following year, a Flemish chronicler heard Schubinger playing in a Mass in Toledo and reported that it 'sounded well with the singers' (bon à oyr avoecq les chantres). ${ }^{9}$

There were some notable exceptions to the one- or two-player norm, however: at the wedding festivities of John the Steadfast (later Archduke of Saxony) and Sophia von

\footnotetext{
${ }^{5}$ Sebastian Virdung, Musica getutscht (Basel, 1511), trans. and ed. B. Bullard (Cambridge, 1993), p.119.

${ }^{6}$ S. Appelbaum (ed.), The Triumph of Maximilian I: 137 woodcuts by Hans Burgkmair and others (New York, 1964), p.5.

${ }^{7}$ Incidentally, Augustein Schubinger trained initially as a trombonist and was not at all unusual in being able to play both instruments in this context. A number of other examples are cited in G. Karstädt, 'Zur Geschichte des Zinken und seiner Verwendung in der Music des 16-18 Jahrhunderts', Archiv für Musikforschung, ii (1937), pp.385-432, at p.416: these include Dietherich Schwartinger 'Drumpter und zinckenpläser' who was employed at the Heidelberg Hofmusik in 1510; and 'Lucas Holland, zinckenbläser und Bassuner' and 'Georg Schmekell, Trummeter und zinkenbläser' who were engaged at the Schweriner Hofkapelle in 1512 and 1515 respectively.

${ }^{8}$ K. Polk, German instrumental music of the late Middle Ages: players, patrons and performance practice (Cambridge, 1992), p.72.

${ }^{9}$ B. Dickey, 'Cornett', in The Cambridge companion to brass instruments, ed. T. Herbert and J. Wallace (Cambridge, 1997), p.52. See also Polk, German instrumental music, p.72 and p.229 n.117.
} 
Mecklenburg in Torgau, 1500, two Masses were sung with 'orgall, three posaun, and a zincken [cornett], and likewise four Cromhorner with the positief. ${ }^{, 10}$ Similarly, in 1503, at a meeting of Maximilian and Philip the Fair in Innsbruck, Mass was celebrated, at which 'the king's sacqueboutes began the Gradual, and played the Deo gratias and Ite missa est. ${ }^{11}$ The number of performers in the latter reference is unspecified, but the most important aspect of this and other contemporary accounts is that they clearly demonstrate the active involvement of the wind instruments in liturgical performance.

The acquisition of a degree of musical literacy was a prerequisite for the inclusion of wind players in such performances. Significantly, in Burgkmair's woodcut the instrumentalists are clearly reading from the large choirbook elevated on a lectern, in what was already a well-established performing practice for singers of liturgical polyphony. ${ }^{12}$ Although we cannot be certain about the precise nature of the instrumentalists' contribution to these performances, the likelihood is that they played the highest and/or lowest vocal parts. ${ }^{13}$ Whether they doubled the singers colla parte, or else replaced the singers on the allocated parts is not clear; either possibility is plausible - and both options are well documented in practices of the later 16 th and 17 th-centuries. ${ }^{14}$

The joining of wind instruments with voices in the early 16 th century represents a significant innovation in the performance practice of liturgical music, which laid the foundation for the expansion of instrumental practice that was to follow from the mid-century onwards. In Munich, for example, the payment records of the Hofkapelle show a single cornett player engaged in 1530 and a trombonist in 1535, perhaps reflecting the influence of Ludwig Senfl; but by 1550 there were at least two cornetts and two trombones in the ensemble. ${ }^{15}$ This model was followed elsewhere, including at St Mark's, Venice, where a

\footnotetext{
${ }^{10}$ S. Carter, The trombone in the Renaissance: a history in pictures and documents (Hillsdale, NY, 2012), p.221.

${ }^{11}$ Carter, The trombone, p.224.

${ }^{12}$ An earlier miniature of this scene (attrib. studio of Albrecht Altdorfer, painted c.1513-16), reproduced in Carter, The trombone, p.235, shows the relationship between instrumentalists and choirbook even more clearly. For a fascinating overview of the practice of singing ad lectrinam see M. Williamson, 'The fate of the choirbook in Protestant Europe', Journal of the Alamire Foundation, vii (2015), pp.117-31.

${ }^{13}$ This is perhaps supported by an account from Bergen op Zoom in 1519 in which a trombonist named Christoffe was paid to play 'bascontre' with the singers, together with a cornettist named Roeland (who, by analogy, presumably played the cantus part); see Polk, 'Augustein Schubinger', pp.88-9.

${ }^{14}$ The most thorough account of these practices is found in Michael Praetorius, Syntagma musicum, iii (1618); English translation J.T. Kite-Powell (Oxford, 2004).

${ }^{15}$ A. Sandberger, Beiträge zur Geschichte der bayerischen Hofkapelle, i (Leipzig, 1894), pp.26, 35; and A. Brinzing, 'Bemerkungen zur Hofkapelle Herzog Wilhelms IV. Mit einer provisorischen Liste der Hofmusiker',
} 
permanent instrumental ensemble was founded in 1568 and subsequently expanded. ${ }^{16}$ In order to understand the full significance of this new practice, it is necessary to consider briefly the traditions of medieval instrumentation from which the cornett emerged.

\section{The medieval classification of instruments: haut and bas}

It is well documented that instrumentation in the 15 th century was governed by the medieval classification of haut and bas (i.e., in this context, loud and soft). ${ }^{17}$ The haut category included all manner of loud instruments such as trumpets, drums and bagpipes alongside the shawms and trombones or slide trumpets of the Stadtpfeiffer tradition from which Augustein Schubinger emerged, and to which his family belonged as a dynasty of professional wind players in Augsburg. The Stadtpfeiffer may also have been described as 'haut' in a quite literal sense: there is some evidence that shawm players habitually transposed their music up a fifth, and thus sounded 'high' in relation to other instruments. As Anthony Baines has pointed out, a comparison of Martin Agricola's fingering charts from Musica instrumentalis deudsch (1529/1545) with his drawings of the shawm and bombarde suggests that these instruments sounded a fifth higher than written. ${ }^{18}$ If the haut instruments of the shawm band were working at a different pitch standard from the bas instruments, this would suggest a clear rationale for separation of these categories in musical practice. ${ }^{19}$

However, the rigid demarcation of haut and bas had already started to break down by the end of the 15 th century, with individual players beginning to transgress the traditional boundaries of their professional activities. For example, Augustein Schubinger was occasionally listed as a player of the lute, in addition to the cornett and trombone. ${ }^{20}$ His brothers, Michel and Ulrich, were employed primarily as shawm players; yet Michel is also

in Die Münchner Hofkapelle des 16. Jahrhunderts im europäischen Kontext, ed. T. Göllner and B. Schmid (Munich, 2006), pp.20-46.

${ }^{16}$ E. Selfridge-Field, Venetian instrumental music from Gabrieli to Vivaldi, 3rd ed. (New York, 1994), pp.1325 .

17 The seminal article on this topic is E. A. Bowles, 'Haut and bas: the grouping of musical instruments in the Middle Ages', Musica Disciplina 8 (1954), 115-40. See Polk, German instrumental music, p.8, for a useful summary of this classification.

18 A. Baines, Woodwind instruments and their history, 3rd ed., (London, 1967), p.233.

${ }^{19}$ Howard Mayer Brown suggests that downward transposition was also common practice among players of bas instruments including the viol and the transverse flute in Germany at this time: H. M. Brown, 'Notes (and transposing notes) on the viol in the early 16th century', in Music in medieval and early modern Europe: patronage, sources and texts, ed. I. Fenlon (Cambridge, 1981), pp.61-78; and 'Notes (and transposing notes) on the transverse flute in the early 16th Century', Journal of the American Musical Instrument Society, xii (1986), pp.5-39.

${ }^{20}$ Polk, 'Augustein Schubinger', p.88. 
recorded as playing the lute and viol, while Ulrich played lute, viol and harp (all the primary instruments of the bas category). ${ }^{21}$

As a newly emerging instrument at this time, the cornett became an important protagonist in this development, since it defied classification according to the traditional scheme. It had a greater dynamic range than other contemporary wind instruments, so it could easily move between the shawm band and bas ensembles - although in the process players had to become adept at transposition to accommodate differences in performing pitch. This flexibility made the cornett a perfect instrument for adapting to the requirements of performing with singers. When it began to do so in the years around 1500 this marked a very significant change, since such a practice would have been unheard of for haut instruments through to the end of the 15 th century.

\section{Vocal styles: da chiesa and da camera}

Numerous sources concur that there was a clear distinction between styles of singing in church and chamber contexts during the 16th century. Gioseffo Zarlino neatly summarized this practice in 1558 :

one sings in one way in churches and public chapels and another way in private rooms. In [the former] one sings in a full voice, but with discretion, nevertheless ... and in private rooms one sings with a lower and gentler voice, without any strepito [noise/din]. ${ }^{22}$

Furthermore, in 1555 Nicola Vicentino indicated that church music was sung with a full voice and with several singers to a part, whereas chamber music was sung softly. ${ }^{23} \mathrm{We}$ can

\footnotetext{
${ }^{21} \mathrm{~K}$. Polk, 'The Schubingers of Augsburg: innovation in Renaissance instrumental music', in Quaestiones in musica: Festschrift für Franz Krautwurst zum 65. Geburtstag, ed. F. Brusniak and H. Leuchtmann (Tutzing, 1989), pp.495-503, at p.496.

${ }^{22}$ Gioseffo Zarlino, Le istitutioni harmoniche (Venice, 1558; edn. of 1588-9), iii: p.253. Translation by R. Wistreich, 'Reconstructing pre-Romantic singing technique' in The Cambridge companion to singing, ed. J. Potter (Cambridge, 2000), pp.178-191, at p.181. I have retained the original 'strepito', which Wistreich translates as 'shouting'. See also R. Wistreich, “"La voce è grata assai, ma ...”: Monteverdi on singing', Early Music, xxii (1994), pp.7-19, at p.8.

23 'nelle chiese... si canterà con le voci piene, \& con moltitudine de cantanti... ma nella musica da camera, cioe quando si cantera piano...' N. Vicentino, L'antica musica ridotta alla moderna prattica (Rome, 1555),book 4, chapter 29. Cited in D. Fallows, 'The performing ensembles in Josquin's sacred music', Tijdschrift van de Vereniging voor Nederlandse Muziekgeschiedenis, xxxv (1985), pp.32-64. Fallows also draws attention to similar comments by Zarlino (as cited by Wistreich, above); and Lodovico Zacconi, Prattica di musica (Venice 1592), book 1, chapter 40. This issue is also discussed in A. Parrott "Falsetto beliefs: the "countertenor" cross examined', Early Music, xliii (2015), pp.79-110, at pp.82-3.
} 
further extrapolate - by comparison with church singing - that chamber singing involved fewer singers, and most likely one singer per part.

The vocal forces employed by Maximilian I clearly reflect this distinction. In 1519 his Innsbruck Hofkapelle included 40 singers: 19 men and 21 boys. ${ }^{24}$ The singers in his travelling entourage, however, included more modest forces: a peripatetic Kapelle of eight singers for liturgical services (all men), and a chamber choir of three or four. ${ }^{25}$ It is interesting to consider if and how a player like Augustein Schubinger might have moved between these different groupings. A further illustration by Burgkmair from the Weisskunig sequence (no.33, c.1514) shows a cornettist (perhaps also Augustein?) playing with four singers reading from a music book in a chamber context (Illus.2). ${ }^{26}$

[insert illus. 2 here, quarter page]

This distinction between vocal styles is highly significant for the instrumentalist seeking to imitate such modes of vocality. Historically, there is evidence that both styles were practised, although the sources suggest that not all cornettists were equally successful at crossing these boundaries. Vincenzo Galilei, for example, took a dim view of cornetts and sackbuts in his Dialogo della musica antica et della moderna (1581):

Cornetti and trombones were invented and introduced into musical ensembles because of the need for sopranos and basses, or should we say, to give them body and volume ... rather than for any good and essential effect that they may have ...

You never hear such instruments in the private chambers of enlightened gentlemen, lords, and princes of taste ... The cornetto, in my opinion, is an instrument to use in armed forces, as once the Spartans employed the aulos, rather than in private chambers. $^{27}$

On the other hand, the most esteemed cornettists of the later 16th and early 17 th centuries were praised for their ability to play extremely quietly, the most celebrated of these being the 'Cavaliere Luigi del Cornetto from Ancona', who, as Vincenzo Giustiniani reported in 1628 ,

played many times in one of my little rooms to the accompaniment of a cembalo which was closed up and could scarcely be heard; and he played the cornett with such

\footnotetext{
${ }^{24}$ W. Senn, Musik und Theater am Hof zu Innsbruck (Innsbruck, 1954), p.38.

${ }^{25}$ Interestingly - and unusually for this period - it seems that the chamber choir included female singers, one of whom would also sing as a soloist, accompanying herself on a variety of instruments. See Polk, German instrumental music, p.90.

26 The lack of a visible detachable mouthpiece might suggests the instrument in question is a mute cornett.

${ }^{27}$ Vincenzo Galilei, Dialogue on ancient and modern music [1581], trans. C. V. Palisca (New Haven, 2003), pp.353-4.
} 
moderation and exactitude that it astonished many gentlemen present ... because the Cornett did not overshadow the sound of the cembalo. ${ }^{28}$

This cornettist was almost certainly Luigi Zenobi, whose famous letter on the qualities of a good musician (c.1600), includes the following advice on this very subject:

[wind players] must cultivate the piano more than the forte, since the former serves for the chambers of princes and in places of respect, and it is the main mode of disclosing the defects and the excellence of the player, which does not occur in bandstands and in chapels and wherever one plays as loud as one can. ${ }^{29}$

Girolamo Dalla Casa also described such differentiation of dynamic level as one of the key characteristics of the cornett that made it able to imitate the voice (1584):

De gli Stromenti di fiato il piu eccellente è il Cornetto per imitar la voce humana piu de gli altri stromenti. Questo stromento si adopera piano, \& forte, \& in ogni sorte di Tuono, si come fa la voce. ${ }^{30}$

Of the wind instruments the most excellent is the cornett, for it imitates the human voice more than the other instruments. This instrument is played piano and forte and in every sort of key [tuono], just as the voice.

The wind players at Durham Cathedral might have done well to heed the advice of Zenobi or Dalla Casa, since some half a century before North's visit they found themselves embroiled in controversy. In 1628 Peter Smart, a prominent puritan and senior prebendary at the cathedral, preached a sermon against a number of 'popish' innovations. Included among his litany of complaints was the practice of 'Sackbuts \& Cornets piping so loud at the communion table, that they may be heard half a mile from the Church. ${ }^{31}$ Although we must account for the likelihood of Smart exaggerating to make his point here (and in keeping with his Puritan principles, he would have been likely to object even to the most restrained and tasteful of wind playing), there is a striking parallel with the full-voiced strepito mentioned by Zarlino. Incidentally, the wind players in Durham at this time were salaried members of the choir, some of whom had moreover received their formative musical training there as boy

\footnotetext{
${ }^{28}$ Vincenzo Giustiniani, Discorso sopra la musica [1628], trans. C. MacClintock, Musicological Studies and Documents, ix (n.p.: American Institute of Musicology, 1962), pp.78-79.

${ }^{29}$ B .J. Blackburn and E. E. Lowinsky, 'Luigi Zenobi and his letter on the perfect musician', Studi musicali, xxii (1993), pp.61-107, at 102 .

${ }^{30}$ Girolamo Dalla Casa, Il vero modo di diminuir (Venice, 1584).

${ }^{31}$ Peter Smart, A Short Treatise of Altars, Altar-furniture, Altar-cringing and Musick of all the Quire, Singingmen and Choristers ([London], 1629), p.19; cited in A. Parrott, 'Grett and Solompne Singing', Early Music, vi (1978), pp.182-187, at p.185.
} 
choristers, so it might be reasonably assumed that their instrumental practice was informed by their experience as church singers. ${ }^{32}$

\section{Transposition practices}

As already observed, transposition must have been fundamental to the cornettist's practice in order to traverse the different performing contexts and pitch standards of the wind band and the chapel choir. Transposition evidently remained an essential part of the cornettist's art until well into the 17th century: Dalla Casa highlighted this in explaining how the instrument plays 'in every sort of key, just as the voice', and Zenobi stated that cornettists are to be judged 'by their ability to play semitones and in transposition where necessary'. ${ }^{33}$

The ability to transpose at an instrument was of crucial importance in an era when vocal notation was understood as a system of relative, rather than absolute pitch. As Andrew Parrott has eloquently summarised, in Renaissance vocal polyphony, 'a set of clefs both defines a work's vocal scoring and suggests its likely overall compass, devolving to the performer the task of establishing an exact pitch level. ${ }^{34}$ In this context of flexible pitch levels, true transposition only becomes an issue when adding a fixed-pitch instrument to the vocal ensemble. Arnolt Schlick's comments on relative pitch in relation to organ building in his Spiegel der Orgelmacher und Organisten (1511) are revealing. First he stated that the organ 'has to be pitched for the choir and tuned suitably for singing', but he then explained how differently sized organs can be built a fifth or an octave apart. ${ }^{35}$ Transposition must therefore have been integral to the organist's technique to reconcile such differently pitched instruments with the natural ranges of voices. ${ }^{36}$

\footnotetext{
${ }^{32}$ B. Crosby, 'The choral foundation of Durham Cathedral, c.1350-c.1650' (PhD thesis, University of Durham, 1993), pp.193-5. Available at Durham E-Theses Online: http://etheses.dur.ac.uk/769/

33 'nel sonar mezzo tuono, e fuora di tuono quando bisognasse'. Blackburn and Lowinsky, 'Luigi Zenobi and his letter', pp.86, 103.

${ }^{34}$ Parrott, 'Falsetto beliefs', p.86.
}

\footnotetext{
${ }^{35}$ Arnolt Schlick, Spiegel der Orgelmacher und Organisten (Mainz, 1511), trans. and ed. E. B. Barber (Buren, 1980), p.27. The question of Schlick's actual or absolute pitch standard is one that has been hotly debated, and is a subject beyond the scope of this article; for further information see, especially, B. Haynes, $A$ history of performing pitch: the story of " $A$ " (Lanham, MD, 1992); E. Segerman, 'A survey of pitch standards before the 19th century', Galpin Society Journal, liv (2001), pp.200-18; W. R. Thomas and J. J. K. Rhodes, 'Schlick, Praetorius and the history of organ-pitch', The Organ Yearbook, xi (1971), pp.58-76.

${ }^{36}$ Also beyond the scope of this article is a fuller discussion of implications of this for the repertory copied and maintained for any particular choir, and which might make sense of the use, and indeed the necessity, of chiavette, or 'transposing' clefs in vocal music.
} 
Schlick also gave instructions for transposition by a whole step in either direction in order to accommodate the singers, ${ }^{37}$ and went on to describe a mechanical device which enabled him to shift the pitch of his own organ up and down by a whole tone. This, he said, is 'especially desirable and useful for measured music where there are competent instrumentalists and singers' ${ }^{38}$

This comment reveals Schlick at the cutting edge of instrument design and innovation in performance practice in his day; as explained above, instrumental participation with singers in church was a very new idea in the early 16th century, and it is perhaps not insignificant that Schlick chose to include on the title page of his treatise a woodcut of a cornettist playing together with an organ and a group of singers (Illus.3). ${ }^{39}$

[Illus.3 insert here, quarter page]

Perhaps the earliest extant music to specify performance on cornett is a set of Sechs und zwentzig fugen auff die acht Tonos by Johann Walter, preserved in a manuscript from the Leipzig Thomaskirche, dated $1542 .{ }^{40}$ These are strict canons in two and three parts, mostly in unison (with three in diapente, i.e. at the fifth), to be played on any similarly tuned instruments, and 'especially on cornetts' (sonderlich auf tzincken). The music is written variously in C3, C4, F3 and F4 clefs, which are evidently chosen to accommodate the eight modes as a series of relative pitches without the need for leger lines, rather than dictating a fixed pitch for the instrumentalist. Indeed, the cornettist would need to play the fugues at least a fifth higher, and in some cases more than an octave above the notated pitch, in order to realise them on a standard treble cornett. For example, the two-part canon in primi toni (Illus.4) could be played a fifth higher or - perhaps more comfortably - an octave higher than written.

\section{[insert illus.4 near here, quarter page]}

One of the most important sources for transposition practice on the cornett is a fingering chart in Aurelio Virgiliano's manuscript treatise, Il dolcimelo (c.1600), reproduced in Illus.5. This is the earliest fingering chart extant for the instrument, and the rubrics on the

\footnotetext{
${ }^{37}$ Schlick, Spiegel, trans. Barber, p.33.

${ }^{38}$ Schlick, Spiegel, trans. Barber, pp.35-7.

${ }^{39}$ See J. Savan, 'From hornet to cornett: in search of the "missing link"', Historic Brass Society Journal, xxiv (2012), pp.1-23, for a fuller discussion of this image.

${ }^{40}$ Leipzig Universitätsbibliothek, MS Thomas 50, fols. $2 r-7 v$ and $14 r-35 r$.
} 
right hand side demonstrate that cornettists understood pitch notation as a relative system. These rubrics require a little interpretation, but Virgiliano essentially indicated that different combinations of clef ( $\mathrm{C}$ or $\mathrm{G})$ and stave signature (indicated by ' $p[e r] \mathrm{b}$ [insert flat sign]' and ' $p[e r] \mathrm{h}$ [insert natural sign]') signal different options for transposition, as extrapolated and summarised in Table 1.

Table 1: Summary of rubrics for transposition in Aurelio Virgiliano's fingering chart for cornett (c.1600).

\begin{tabular}{|l|l|l|}
\hline Clef & Stave signature & Options for transposition \\
\hline C & none (natural) & $\begin{array}{l}\text { A fifth higher } \\
\text { At notated pitch } \\
\text { A tone lower }\end{array}$ \\
\hline C & flat & $\begin{array}{l}\text { A fifth higher } \\
\text { A tone higher } \\
\text { At pitch } \\
\text { A tone lower }\end{array}$ \\
\hline C & unspecified & A minor third lower \\
\hline G & none (natural) & $\begin{array}{l}\text { At pitch } \\
\text { A fourth lower } \\
\text { A fifth lower }\end{array}$ \\
\hline G & flat & $\begin{array}{l}\text { A tone higher } \\
\text { At pitch } \\
\text { A fourth lower } \\
\text { A fifth lower }\end{array}$ \\
\hline G & unspecified & A sixth lower \\
& & A seventh lower \\
\hline
\end{tabular}

These options clearly extend beyond the established conventions of downward transposition of a fourth or a fifth for chiavette clefs, for instance as applied to the famous instance of the seven-voice Magnificat in Monteverdi's 1610 Vespers, which has been discussed at great length in this journal since Andrew Parrott's seminal article of $1984 .{ }^{41}$ Virgiliano's chart suggests a greater flexibility of practice, and one which might have been of

\footnotetext{
${ }^{41}$ A. Parrott, 'Transposition in Monteverdi's Vespers of 1610: An “aberration” defended', Early Music, xii (1984), pp.490-516.
} 
practical benefit for an instrumentalist working between different geographical locations and performing contexts that used alternative pitch levels. Schlick's description of the organ showed that transposition by a fourth or fifth in either direction had an immediate practical application, as did transposition by a whole tone. Perhaps less obviously, downward transposition by a minor third would have been advantageous to a cornettist from the north of Italy performing in Rome, for instance, where by c.1600 (and lasting well into the 18th century) the organ pitch was typically a minor third lower (at around $a^{\prime}=390 \mathrm{~Hz}$, as compared to an average in northern Italy of $\left.a^{\prime}=466 \mathrm{~Hz}\right) .{ }^{42}$ Similarly, in England, minor-third transposition would have provided a practical means of reconciling Quire and Consort pitch (at around $a^{\prime}=473 \mathrm{~Hz}$ and $a^{\prime}=400 \mathrm{~Hz}$ respectively) - pitch relationships that can be established through the evidence of recorders and other surviving wind instruments from the 17 th century, and which are likely to have pertained during the 16 th century also. ${ }^{43}$ Indeed, a fingering chart preserved in James Talbot's manuscript, purportedly relating to an instrument in the possession of trumpeter John Shore, shows that the cornett was reconceptualised as a consort pitch instrument 'in $C$ ' in the later 17 th century, presumably to match the newer French-influenced woodwinds that were becoming fashionable in England at that time. Talbot's chart is an important piece of evidence demonstrating how transposed fingerings allowed the high-pitch cornett to integrate with low-pitch music (Illus.6). ${ }^{44}$

\section{[insert illus.6 near here, full width of page]}

John Shore's cornett was somewhat unusual, in that it seems to have overblown at the octave. One of the acoustical idiosyncrasies of the majority of cornetts is that with all fingerholes closed, they overblow at a minor ninth - thus producing the note $b$-flat'. However, this note is extremely low (up to a quarter tone flat) on many extant cornetts of the late 16th and early 17 th centuries, such that it accords more closely with $a$-sharp' than $b$-flat' in mean-tone tuning (and thus the overblown interval might more accurately be described as

\footnotetext{
${ }^{42}$ Haynes, A history of performing pitch, pp.58-75.

${ }^{43}$ Haynes, A history of performing pitch, pp.88-96. See also A. Johnstone, “"As it was in the beginning”: organ and choir pitch in early Anglican church music', Early Music, xxxi (2003), pp.506-25.

${ }^{44}$ Oxford, Christ Church Library, Music MS. 1187; the cornett tablature is located at Folder 9, p.7. Talbot provides two alternative sets of measurements for the cornett in question, and while the status of these measurements is therefore somewhat ambiguous, it is clear that the general dimensions of the instrument are consistent with those of the majority of surviving treble cornetts at the prevailing 'high' pitch standard in the region of $a^{\prime}=466 \mathrm{~Hz}$. See A. Baines, 'James Talbot's manuscript. (Christ Church Library Music MS 1187). I: wind instruments,' Galpin Society Journal, i (1948), pp.9-26.
} 
an augmented octave). ${ }^{45}$ The tuning of this note can often be improved considerably by opening the thumbhole (and sometimes the first fingerhole), but most modern cornett makers have elected instead to solve this perceived problem by shortening the instrument slightly at the bell end and thus raising the pitch. However, when transposing, such a low all-closed note can be advantageous. When playing up a tone this fingering is required for $g$-sharp', and playing down a minor third it is required for c-sharp'; having these notes sound at a somewhat lower pitch is especially useful for playing pure intervals in just intonation with $a$ cappella singers, or in matching the mean-tone temperament of an organ. In other words, it enables the player to make a distinction (diesis) between enharmonic notes, which is essential in being able to maintain consistency of intonation when transposing. Such attention to the enharmonic diesis is probably what Zenobi meant when describing how the cornettist must be able 'to play semitones ... in transposition' (see above). Similarly, in 1594 the Bolognese theorist Hercole Bottrigari described the cornett as a 'stable but alterable' instrument, the intonation of which 'can be changed, augmented or diminished in some degree, according to the good judgement of the player', ${ }^{46}$

A clear link between instrumental and vocal transposition practice may be seen in the earliest printed source in England to specify performance on the cornett: Thomas Whythorne's Duos, or Songs for two voices (London, 1590). The second part of this collection was 'made for two children to sing. Also they be aptly made for two treble Cornets to play or sound' ${ }^{47}$ This section contains fifteen duets, written in various combinations of $\mathrm{C} 1$ and C2 clefs, all with flat stave signatures, of which eleven descend to $g$, one tone below the normal range of the treble cornett. Although this note is playable with a relaxed embouchure (and facilitated by the longer sounding-length of some historical instruments), it remains difficult to sound, requiring a technique beyond that of the 'young beginners' who were Whythorne's intended recipients. Transposition upwards by either a tone or a fifth (as suggested by Virgiliano) remedies the problem, rendering the pieces more easily playable on the cornett, and also bringing them within the range of the boy-treble voice.

Through these various examples it can be seen that transposition enabled the cornettist to adapt to the flexible pitch of a cappella singing. Transposition also enabled the

\footnotetext{
${ }^{45}$ This issue is discussed in detail in J. Savan, 'Unlocking the mysteries of the Venetian cornett: ad imitar piu la voce humana', Historic Brass Society Journal, xxviii (2016), pp.31-55.

${ }^{46}$ Hercole Bottrigari, Il Desiderio [1594], trans. C. MacClintock, Musicological Studies and Documents, ix (n.p.: American Institute of Musicology, 1962), p.15.

47 Thomas Whythorne, Duos, or Songs for two voices (London, 1590), title page.
} 
cornettist to traverse fixed pitch standards across different locations and performing contexts. Moreover, a study of extant cornetts of the late 16th and early 17 th centuries suggests that many were constructed with transposition in mind, since their fingering systems facilitate playing in seemingly remote keys. Illus.7 is an extract from Frescobaldi's Canzon prima, from his collection Canzoni da sonare, which was first published in Rome (1628), and followed by a second edition in Venice (1634). If using a church organ as continuo instrument this piece would have sounded at very different pitches in these two locations. Audio example 1a is a version of this extract performed with organ and cornett both tuned to $a^{\prime}=471 \mathrm{~Hz}$. Audio example $1 \mathrm{~b}$ is performed with the organ tuned to $a^{\prime}=395 \mathrm{~Hz}$, whereas the cornett remains at $a^{\prime}=471 \mathrm{~Hz}$ and transposes down a minor third. Note that this requires the cornettist to a cadence in F-sharp major at the conclusion of the triple-time section. The cornett, made by John McCann, is a copy of an instrument in the Kunsthistorischen Museum, Vienna (SAM 230), which follows the historical Venetian fingering system.

\section{Pedagogy and solmization}

Whythorne's fifteen equal-voice duets are untexted, and so if sung by children (rather than played instrumentally), they would most likely have been sung to solmization syllables. ${ }^{48}$ The practice of hexachordal solmization is one of the most interesting ways in which vocal and instrumental pedagogy converge during this period. Anne Smith has drawn attention to a range of historical sources that describe how solmization might influence a musician's approach to phrasing and shaping the musical line, and how the timbral characteristics of individual notes might be influenced by their associated solmization syllable, with a particular distinction between $m i$ and $f a$ respectively as 'hard' and 'soft' syllables. ${ }^{49}$ This practice, she argues, applied as much to instrumentalists as to singers, observing that 'the weaker forked fingerings on wind instruments are often associated with notes that would be sung with a $f a .{ }^{50}$ This can be seen clearly in illus.8, one the fingering charts for recorder in Silvestro Ganassi's treatise Fontegara (Venice, 1535). Assuming a recorder 'in C', the syllables applied here are those of the 'natural' and 'soft' hexachords (starting on $\mathrm{C}$ and $\mathrm{F}$

\footnotetext{
${ }^{48}$ That this was a common practice is attested by British Library Add. Ms. 31390, 'A booke of In nomines \& other solfainge sounges ... for voyces or Instrumentes': 127 folios of untexted pieces by Byrd and others in table book format.

${ }^{49}$ A. Smith, The performance of 16th-century music: learning from the theorists (New York, 2011), pp.20-54.

${ }^{50}$ Smith, The performance of 16th-century music, p.29.
} 
respectively), in which the notes $\mathrm{F}$ and B-flat are solmized as $f a$, and played with 'forked' cross-fingering.

Insert illus. 8 near here, across full page width

The same principle may be seen in Virgiliano's cornett chart (illus.5), in which the bottom note, A, is marked re. This denotes that it is the second degree of the 'hard' hexachord (on G), which interlocks with the 'natural' hexachord (on C). In these hexachords the notes $\mathrm{C}$ and $\mathrm{F}$ are solmized as $f a$ - and indeed these notes are shown with forked fingerings. The forked $\mathrm{C}$ is a characteristic of extant historical cornetts of the 16th and early 17 th centuries, and results in a considerably softer sound, especially in relation to the B natural (as $m i$ ) which tends to sound rather more strident; the same is true for the forked $\mathrm{F}$ in relation to E natural. Virgiliano did not include fingerings for chromatic notes in his scheme, but I have made a detailed study of the enharmonic fingerings available on several extant Venetian cornetts in Oxford, Verona and Vienna, which reveals that most sharp notes can be played with a simple, unforked fingering, whereas all the flat notes require various degrees of forked or cross fingering. ${ }^{51}$ This allows not only for a differentiation of pitch between sharps and flats (in accordance with historical mean-tone tuning systems) but also results in a fundamentally different sound quality, the sharps according more with a $m i$ character, the flats with $f a$.

The final, chromatic, section from Giovanni Paolo Cima's Sonata per cornetto from his Concerti ecclesiastici (Milan, 1610) can be heard in Audio example 2, which demonstrates the heterogeneous tone quality produced by these historical fingerings.

These fingerings also facilitate certain kinds of transposition, especially when playing up one tone or down a third, as described above; and indeed, for the most part, the Venetian instruments seem to allow for a continued (if less pronounced) differentiation of $m i$ - and $f a$ character notes even in transposition. ${ }^{52}$

Later cornett fingering charts, starting with Daniel Speer in 1697, give a simple, unforked, fingering for $\mathrm{C}$, which is required for some original instruments from this later period, and is the principle adopted by the majority of modern cornett makers. ${ }^{53}$ Most modern cornetts are also built so that the high $f$ " may be played with all holes closed, thus removing

\footnotetext{
${ }^{51}$ Savan, 'Unlocking the mysteries', pp.39-50.

${ }^{52}$ A full enharmonic fingering scheme for the 'Venetian' system is given in Savan, 'Unlocking the mysteries', p.47.

${ }^{53}$ Daniel Speer, Grund-richtiger ... Unterricht der Musicalischen Kunst (Ulm, 1697); see Savan, 'Unlocking the mysteries', pp.31-33.
} 
the need for forked fingering. This results in an instrument with a more homogenous sound throughout its range, and simplifies certain kinds of passagework considerably. But in the process the link between historical forked fingerings and solmization practice as a fundamental aspect of imitating the voice has been lost.

Audio example 3 demonstrates vocal and instrumental solmization by applying appropriate syllables to Johann Walter's two-part canon in primi toni (Illus.4), performed by soprano (Faye Newton) and cornett in imitation.

\section{Articulation: imitation of the voice in parlare and cantare}

Perhaps the most direct link between vocality and wind playing is found in the technical study of articulation. A number of 16th- and early 17th-century diminution treatises contain instructions and exercises for articulation on wind instruments. Few, however, contain as detailed a rationale for the importance of articulation as Ganassi did in Fontegara, which although written ostensibly for the recorder is equally applicable to the cornett (a point perhaps emphasised by the inclusion of a pair of cornetts in the woodcut illustration on the title page of his treatise):

Voi hauete a sapere come tutti li instrumenti musicali sono rispetto \& comparatione ala uoce humana mancho degni per tanto noi si afforzeremo da quella imparare \& imitarla: onde tu potresti dire come sara possibile conciosia cosa che essa proferisce ogni parlare dil che non credo che dito flauto mai sia simile ad essa humana uoce \& io te rispondo che cosi come il degno \& perfetto dipintor imita ogni cosa creata ala natura con la uariation di colori cosi con tale instrumento di fiato \& corde potrai imitare el proferire che fa la humana uoce...

\& si il dipintore imita li effetti de natura con uarii colori lo instrumento imitera il proferir della humana uoce con la proportion del fiato \& offuscation della lingua con lo agiuto de deti \& di questo ne o fatto esperientia \& audito da altri sonatori farsi intendere con il suo sonar le pole di essa cosa che si poteua ben dire a quello inftrumento non mancarli altro che la forma dil corpo humano si come si dice ala pintura ben fatta non mancarli solum il fiato: si che haueti a essere certi del suo termine per dite rason de poter imitar il parlar. ${ }^{54}$

You should know how all the musical instruments, in comparison with the human voice, are lacking. For that reason we should strive to learn from and to imitate it. You may say: 'How is this possible with everything that it can pronounce, all of its speaking'; and you may say, 'I do not believe that this flute could ever be similar to the human voice.' And I respond that just as the worthy and perfect painter imitates

\footnotetext{
${ }^{54}$ Silvestro Ganassi, Opera intitulata Fontegara (Venice, 1535), [2-3; unpaginated]. Contractions are tacitly expanded.
} 
everything created by Nature by the variation of colours, thus with those wind and string instruments you can imitate the pronunciation of the human voice...

If the painter imitates the effects of nature by varying the colours, so the instrument imitates the pronunciation of the human voice by the [changing] proportion of air and the shading [offuscatione] of the tongue with the addition of the fingers, and in this I have experience and have heard other players make the words so comprehensible through their playing that it could be said that nothing was lacking to that instrument but the form of the human body, just as one says of a well-made painting that nothing is missing but the breath. Thus for these reasons you should be sure of your aim: imitate speech. ${ }^{55}$

Ganassi's emphasis on imitating speech, and the pronunciation of individual words, explains the great variety of articulation syllables and patterns enumerated in his treatise, as summarised in Table $2 .{ }^{56}$ He divided the principal types of tonguing into three categories, according to the scheme found also in later treatises, but in combining the consonants with different vowels, his sub-types were more expansive than those of any other writer on the subject.

Table 2: Ganassi, Dimostratione de varie sorte de lingua (demonstration of the various kinds of tonguing)

\begin{tabular}{|l|l|l|}
\hline Primo $^{57}$ & Secondo & Terzo \\
\hline te-che te-che te-che te-che te-che & te-re te-re te-re te-re te-re & le-re le-re le-re le-re le-re \\
ta-cha te-che ti-chi to-cho tu-chu & ta-ra te-re ti-ri to-ro tu-ru \\
da-cha de-che di-chi do-cho du-chu & $\begin{array}{l}\text { da-ra da-re da-ri da-ro-da-ru } \\
\text { cha-ra cha-re cha-ri cha-ro cha-ru }\end{array}$ & \\
& \\
\hline
\end{tabular}

Ganassi was probably not just talking about imitating everyday speech patterns, but rather a heightened form of oration informed by classical rhetoric, one of the foundations of the studia humanitatis (with which he was evidently familiar, since he cited Socrates, Plato, Aristotle and Aristoxenus in the preface to his treatise). Ganassi explicitly compared musical

\footnotetext{
55 Translation kindly provided by Bruce Dickey (email to author, 17 November 2016). Note that the emphasis here on parlare as speech differs substantially from Dorothy Swainson's translation in the familiar Robert Lienau Musikverlag edition of 1959, which was based on Hildemarie Peter's German translation of 1956.

${ }^{56}$ Ganassi, Opera intitulata Fontegara, [10]. For a translation of Ganassi's detailed technical instructions for articulation see E. H. Tarr and B. Dickey, Bläserartikulation in der alten Music / Articulation in early wind music (Winterthur, 2007), pp.41-45.

${ }^{57}$ Note 'ch' in Italian is pronounced ' $\mathrm{k}$ ', and not as the 'ch' in church; the articulations in Ganassi's 'Primo' category are therefore rather similar to the modern double tongue, tu-ku.
} 
execution to the delivery of an orator in Regola Rubertina (1542), as did Vicentino in L'antica musica... (1555), and indeed the central role of rhetoric is reiterated in much of the pedagogical literature of the later 16 th and 17 th centuries. ${ }^{58}$

But there is perhaps a more specific context to Ganassi's discussion of imitation of the voice in parlare. Pietro Bembo, Italy's leading literary scholar and rhetorician, had taken up residence in Venice as the city's official historian in 1530, and it was around this time that he was developing new ideas about the affective potential of words-as-sounds (as distinct from words-as-names) that were to have profound importance for the subsequent development of the madrigal, for instance under the musical leadership of Adrian Willaert (maestro di cappella at St Mark's since 1527). ${ }^{59}$ Bembo and his circle believed that the sounds and rhythms of words were the primary means to achieving the rhetorical qualities of gravità (majesty) and piacevolezza (sweetness). ${ }^{60}$ Such preoccupations were very much part of the cultural milieu in which Ganassi worked as a piffaro (and quite possibly a cornetto player) of the Doge, and might very well explain his particular focus on imitating the pronunciation and sonorous quality of individual words. ${ }^{61}$

Another aspect of wind articulation, however, is related to imitation of the singing (rather than the speaking) voice, and in particular the gorgia (throat) articulations used by singers in the execution of fast passagework, as Francesco Rognoni described in 1620:

The cornetto is an instrument which partakes more in the [qualities of the] human voice than does any other... you should play it with discretion and delicacy, seeking to imitate the human voice; and the tongue should be neither too dead, nor too [harshly] struck, but rather should be similar to the gorgia. These are the elements necessary for mastery of the instrument. ${ }^{62}$

\footnotetext{
${ }^{58}$ Ganassi, Regola Rubertina (Venice, 1642), p.6 (chapter 2); Vicentino, L'antica musica ridotta alla moderna pratica (Rome, 1555), fol. 88v (recte 94v). These and other relevant sources are cited in Smith, The performance of 16th-century music, pp.103-108. Such comparisons between musical performance and oration continue into the mid-18th century, perhaps most famously in J. J. Quantz, Versuch einer Anweisung die Flöte traversiere zu spielen (Berlin, 1752), p.100. Chapter 11, entitled 'Vom guten Vortrage im Singen und Spielen überhaupt' ('On good speech in singing and playing in general') explains that 'the musical performance can be compared with the performance of an orator' ('Der musikalische Vortrag kann mit dem Vortrage eines Redners verglichen werden').

${ }^{59}$ D. T. Mace, 'Pietro Bembo and the literary origins of the Italian madrigal', The Musical Quarterly, lv (1969), pp.65-86.

${ }^{60}$ Mace, 'Pietro Bembo', p.69.

${ }^{61}$ I am grateful to Catherine Motuz for suggesting this connection.

${ }^{62}$ Francesco Rognoni, Selva de varii passaggi, parte seconda (Milan, 1620), p.4; translation by B. Dickey in his editor's preface to Riccardo Rognoni, Passaggi per potersi essercitare nel diminuire (1592; facsimile edition, Bologna, 2007), p.42.
} 
Both Rognoni and Dalla Casa explained that the principal means of emulating the gorgia technique was the lingua riversa ('reversed tongue'), namely the articulations of Ganassi's third category (le-re le-re, etc.). ${ }^{63}$ Instrumentalists were further encouraged to imitate the ornamentation of vocalists, for which mastery of the gorgia provided a technical foundation. Zenobi advised that the soprano singer 'has the obligation and complete freedom to improvise diminutions, to indulge in playfulness (scherzare), and, in a word, to ornament a musical body... he must have a rich repertoire of passaggi and good judgement as to how to use them... He must use different passaggi in the same songs, he must know how to improvise them in every kind of vocal music'. ${ }^{64} \mathrm{He}$ went on to explain that, 'all the requirements described above, or the greater part of them, are sought in an instrumentalist'. ${ }^{65}$ However, he also cautioned that, 'unless this is done with art, with grace, and with good taste, it is annoying to hear, hard to digest, and loathsome to endure. ${ }^{66}$

Hercole Bottrigari describes hearing the ideal union of voices and instruments at the convent of San Vito in Ferrara, where the nuns played cornetts and trombones:

with such grace and such a nice manner, and such sonorous and just intonation... that even people who are esteemed most excellent in the profession confess that it is incredible... And their passagework is not of the kind that is chopped up, furious, and continuous, such that it spoils and distorts the principal air... but at times and in certain places there are such light, vivacious embellishments that they enhance the music and give it the greatest spirit. ${ }^{67}$

In summary, historical sources of wind articulation seem to emphasise two main aspects of imitating the voice - advocating firstly the use of different consonant and vowel combinations in imitation of rhetorical speech patterns; and secondly advocating the use of the lingua riversa in imitation of the gorgia articulation of the singers, as a key component in the successful execution of elegant and virtuosic passagework. Mastery of the lingua riversa and gorgia remains one of the most significant challenges for performers today, since these techniques are very far removed from modern pedagogical practices for wind players and singers.

\footnotetext{
${ }^{63}$ See Wistreich, “"La voce è grata assai, ma ..." for more on the gorgia technique.

${ }^{64}$ Blackburn and Lowinsky, 'Luigi Zenobi and his letter', pp.101-2.

${ }^{65}$ Blackburn and Lowinsky, 'Luigi Zenobi and his letter', p.102.

${ }^{66}$ Blackburn and Lowinsky, 'Luigi Zenobi and his letter', p.101.

${ }^{67}$ Bottrigari, Il desiderio, trans. MacClintock, p.60.
} 


\section{The soprano voice: models for imitation}

We have so far considered a number of important attributes of vocal practices that might have been imitated by an instrumentalist during the 16th and 17th centuries. These included musical literacy - an ability to read from choirbooks and partbooks; an ability to moderate dynamics according to the performing context; flexibility in performing pitch (and, for the instrumentalist, facility in transposition); a knowledge of hexachordal solmization and an understanding of the tonal characteristics associated with the different solmization syllables; an understanding of rhetoric in speech and song; clarity and variety in articulation; and technical fluency in ornamentation.

However, we have not yet addressed the biggest question of all. The cornett is of course a soprano instrument, and so the voice it will imitate most closely will be in the soprano register. But who sang the soprano at this time? Bottrigari's reference to the excellence of female performers (above) throws the issue of gender into relief, especially when juxtaposed with Zenobi's account of the ideal soprano voice, whose qualities are enumerated using exclusively masculine pronouns. Although normatively female in modern usage, the term 'soprano' encountered in the historical sources can in fact refer to a variety of voice types, often categorised via binary divisions: female versus male; adult versus child; natural versus unnatural. ${ }^{68}$ Thus there are multiple archetypes for the historical soprano, each of which raises its own set of questions and problems as a potential model for imitation.

The role of women in church music was heavily circumscribed, and beyond the convents (where the singing and playing of nuns is well documented), 'soprano' usually meant a male voice in this context. In the secular sphere, women sang under heavy stricture of social convention, with the resulting irony that the most celebrated female singers of the later 16th century, the concerto delle donne of Ferrara, were famous for singing in 'secret' concerts heard only by the relatively few courtiers and high-ranking dignitaries deemed worthy of invitation. Although a musician of Luigi Zenobi's rank may have had privileged access to these concerts, his experience can hardly be typical of the average professional wind player seeking out vocal models for his art.

\footnotetext{
${ }^{68}$ For a useful discussion of these issues in Italy see R. Wistreich, "'Il soprano e veramente l'ornamento di tutte l'altre parti': Soprani, Castrati, Falsettisti and the performance of late Renaissance Italian secular music', in Der Countertenor: die männliche Falsettstimme vom Mittelalter zur Gegenwart, ed. C. Herr and A. Jacobshagen (Mainz, 2012), pp.65-78.
} 
The notion of imitating the sound of a boy treble might seem a relatively straightforward prospect, and the Anglican choral tradition ostensibly represents a direct link to the sonorities of the 16th or 17 th centuries. However, as Timothy Day has shown, the "pure white tone' of the English chorister probably has much more to do with anti-Romantic aesthetic preferences of the 20th century than with pre-Romantic performance practices. ${ }^{69}$ Moreover, for numerous contemporary commentators (including Roger North), the raison d'être of cornettists performing in church choirs was in fact to mitigate the deficiencies of the boy choristers, who thus provide a less-than-perfect model.

Although the putative role of the falsettist in English church music prior to the Civil War has now been comprehensively debunked by Simon Ravens and Andrew Parrott, it is interesting to note that the 'first clear indication of falsetto singing on English soil' is found in conjunction with the cornett, as a pragmatic response to the lack of suitably trained boys following the Restoration. ${ }^{70}$ According to Matthew Locke,

for above a Year after the Opening of His Majesties Chappel [in 1660], the Orderers of the Musick there, were necessitated to supply the superiour Parts of their Musick with Cornets and Mens feigned Voices, there being not one Lad, for all that time, capable of Singing his Part readily. ${ }^{71}$

On the other hand, the emergence of the falsettist in Italy is well documented during the 16th century, by the end of which it was clearly well established as an alternative to boys' voices in the chapel choirs, and also as a solo voice in chamber music. ${ }^{72}$ One of the most celebrated of these was Giovanni Luca Conforto, whom Pietro Della Valle described as a great singer of gorge and passaggi, and could sing 'as high as the stars' (che andava alto alle stelle). ${ }^{73}$ Nevertheless, Della Valle made a clear distinction between falsetti and soprani naturali, the latter category including both boys and castrati. Whereas boy sopranos were no sooner trained than their voices were lost, and this before they had learned proper musical judgement (giudizio), taste (gusto) and grace (grazia), the castrati continued their vocal and

\footnotetext{
${ }^{69}$ T. Day, 'English cathedral choirs in the 20th century', in The Cambridge companion to Singing, ed. J. Potter (Cambridge, 2000), p.132.

${ }^{70}$ S. Ravens, The Supernatural Voice: A History of High Male Singing (Woodbridge, 2014), pp.71-89; A. Parrott, 'Falsetto beliefs', p.93.

${ }^{71}$ Matthew Locke, The Present Practice of Musick Vindicated (London, 1673), 19; cited in Parrott, 'Falsetto beliefs', p.93.

${ }^{72}$ Andrew Parrott provides a most useful series of documents to this effect in Composers' Intentions?: Lost traditions of musical performance (Woodbridge, 2015), Appendix 7, pp.112-9.

${ }^{73}$ Pietro Della Valle, Della musica dell'età nostra che non è punto inferiore, anzi è migliore de quella dell'età passata [1640]; published in A. Solerti, Le origini del melodrammma (Turin, 1903), pp.148-179, at p.162.
} 
artistic development into adulthood and were thus highly prized. ${ }^{74}$ The sound of a "choice eunuch' may now be impossible to recreate, but for all that the cornett was in its own day extolled as a paragon of vocal emulation, perhaps now, conversely, it can provide a tangible link to some of the lost vocal practices and sonorities of the past.

\section{Biography}

Jamie Savan is Professor of Performance-led Research in Music at the Royal Birmingham Conservatoire, Birmingham City University. Integrating research and practice as a professional cornettist, his current work focuses on the intersection of organology and historical performance practice in the early modern period. He is founder-director of The Gonzaga Band, a member of His Majestys Sagbutts \& Cornetts, and an orchestral principal with the English Baroque Soloists.

jamie.savan@bcu.ac.uk

Extracts from this paper were read at the Vocality/Instrumentality conference at the University of Huddersfield (January, 2017), and at Andrew Parrot's Taverner Symposium (April, 2017).

\section{Abstract}

'Imitate the human voice' is a familiar exhortation to instrumentalists in the pedagogical literature of the 16th and 17th centuries. In 1584 Girolamo Dalla Casa stated that the cornett is the most excellent of all wind instruments precisely on account of its ability to imitate the human voice. But what does it mean to imitate the voice in practical terms? To what extent does the 'vocality' of the cornett extend beyond a simple comparison of tone quality with that of 'a boy's voice' (Luigi Zenobi, c.1600) or 'a choice eunuch' (Roger North, 1676)? This article explores ways in which different models and understandings of vocality inform the literature and pedagogy of instrumental performance practice in the 16th and early 17 th centuries. It also explores ways in which techniques connected with vocal music such as solmization and transposition practices are embodied in the design and construction of historical instruments, which often have quite different characteristics to the generic 'modern' cornetts more commonly played today.

\footnotetext{
${ }^{74}$ Della Valle, Della musica, p.163.
} 
Illustrations

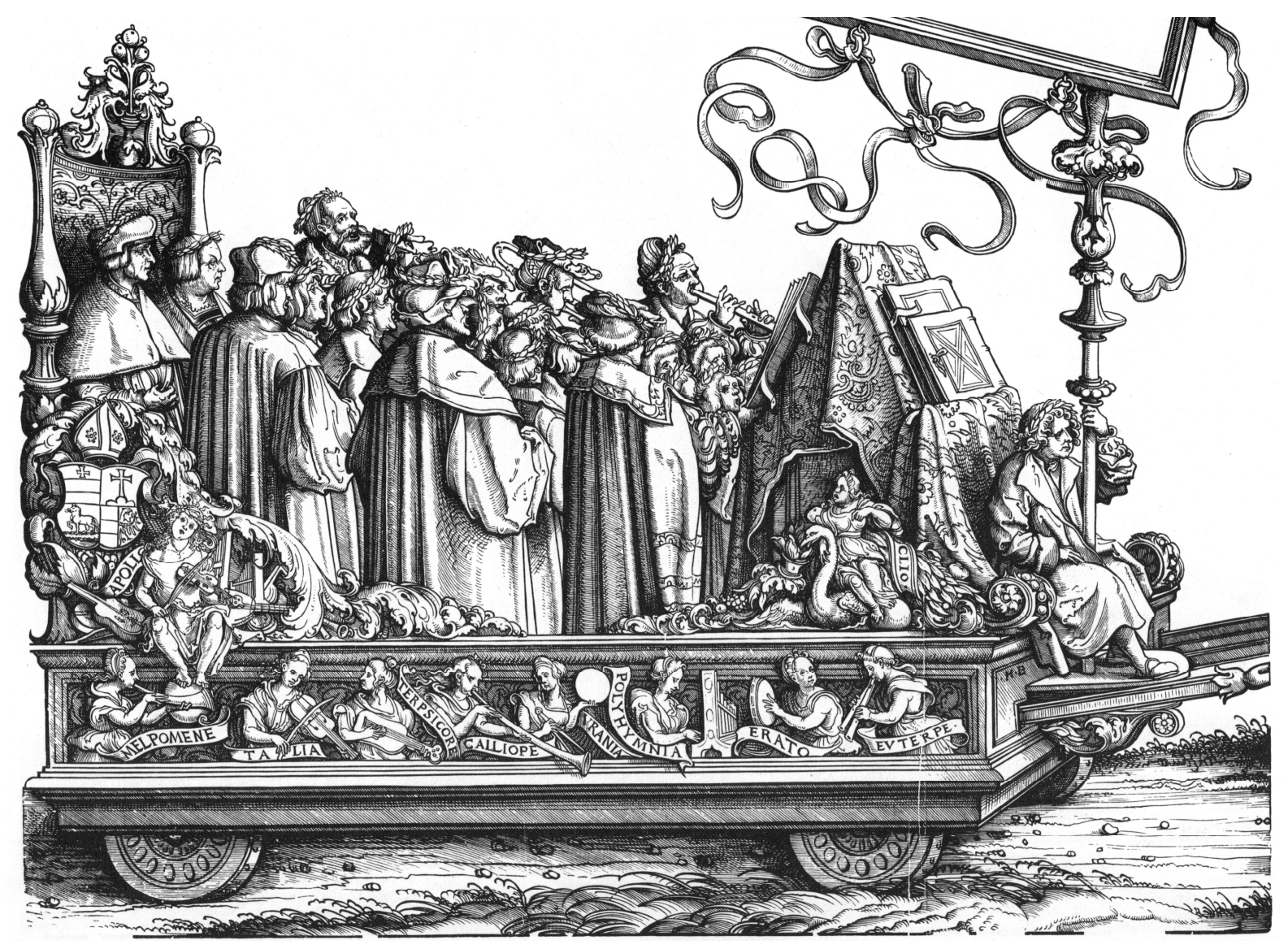

Illus.1: The Imperial Hofkapelle of Emperor Maximilian I, from the Triumph of Maximilian. Woodcut by Hans Burgkmair, first printed 1526. 


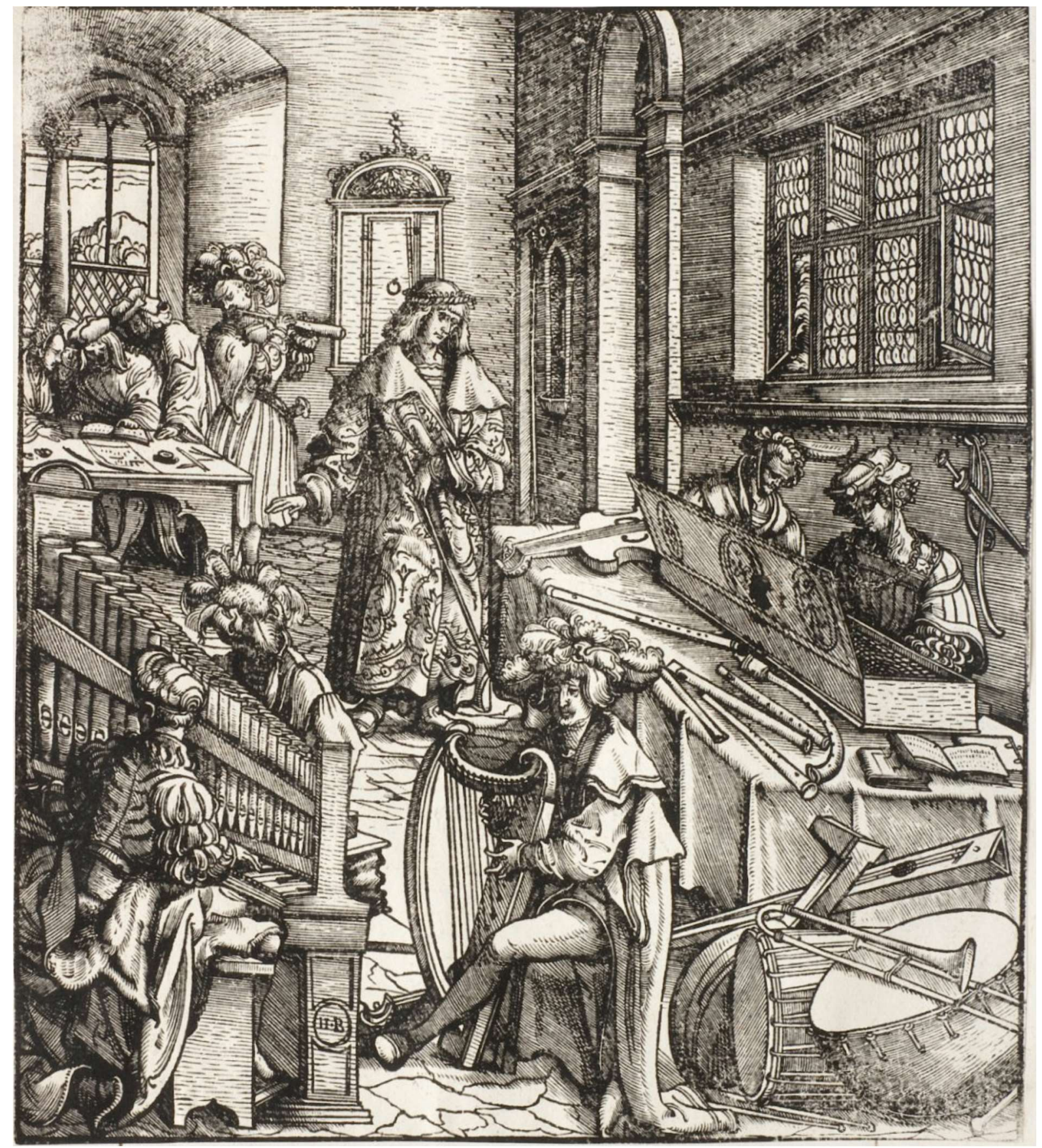

Illus.2: 'How the young Weisskunig learned to know music and string instruments'. Woodcut by Hans Burgkmair (c.1514). 


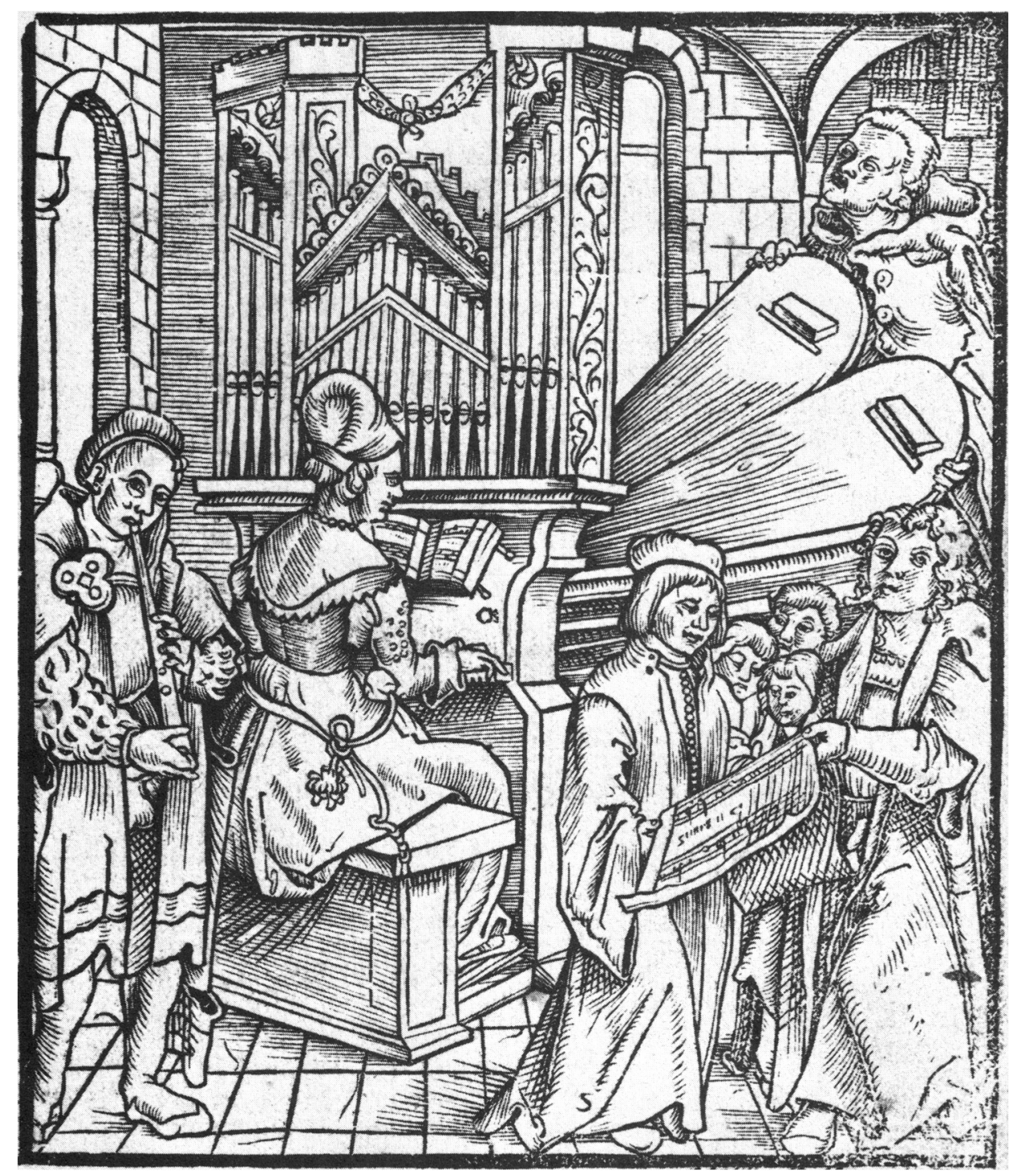

Illus.3: Arnolt Schlick, Spiegel der Orgelmacher und Organisten (Mainz, 1511), title page image. 


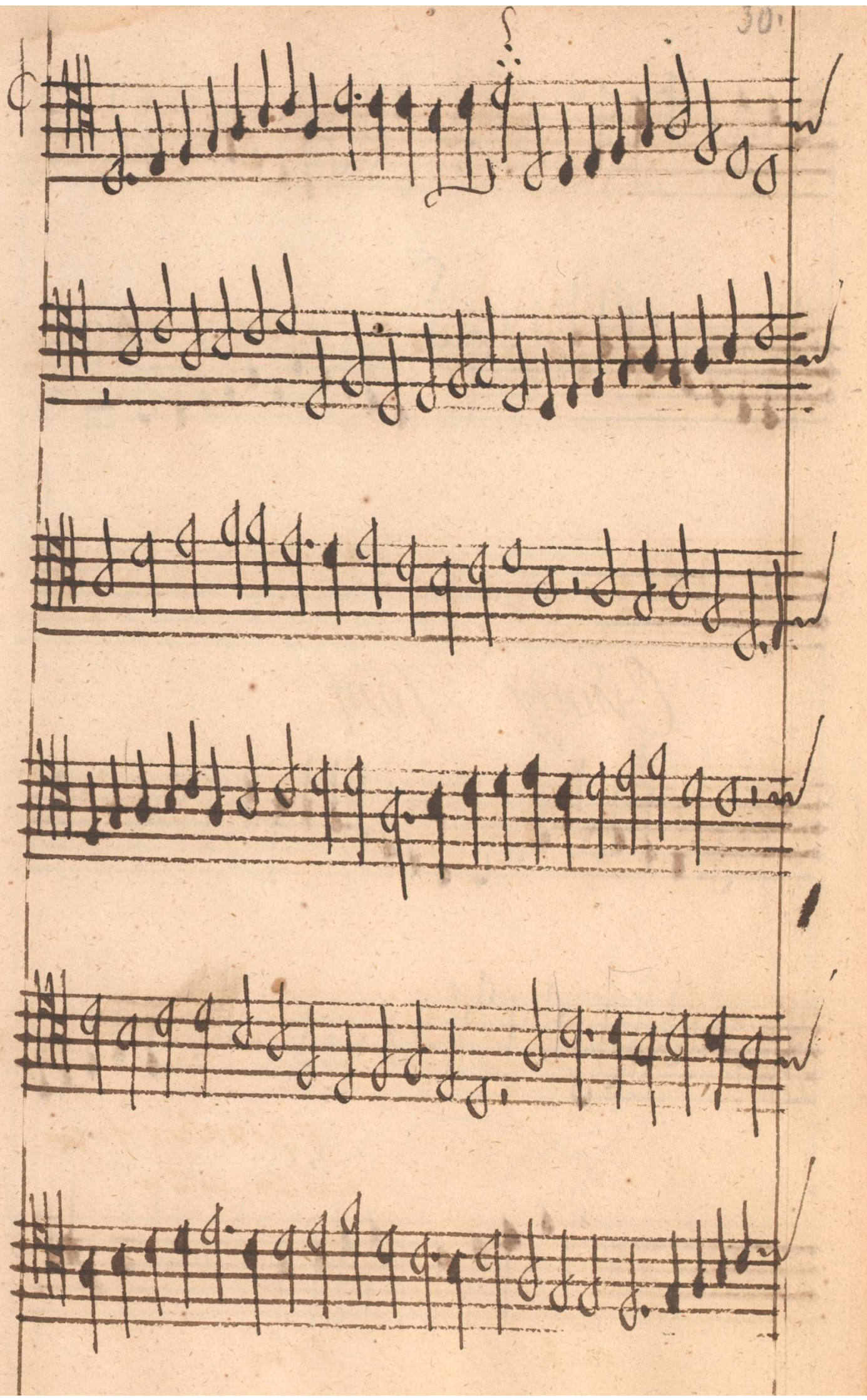

Illus.4: Johann Walter, two-part canon in primi toni, from Sechs und zwentzig fugen auff die acht Tonos, Leipzig Universitätsbibliothek, MS Thomas 50, fol.30r. 


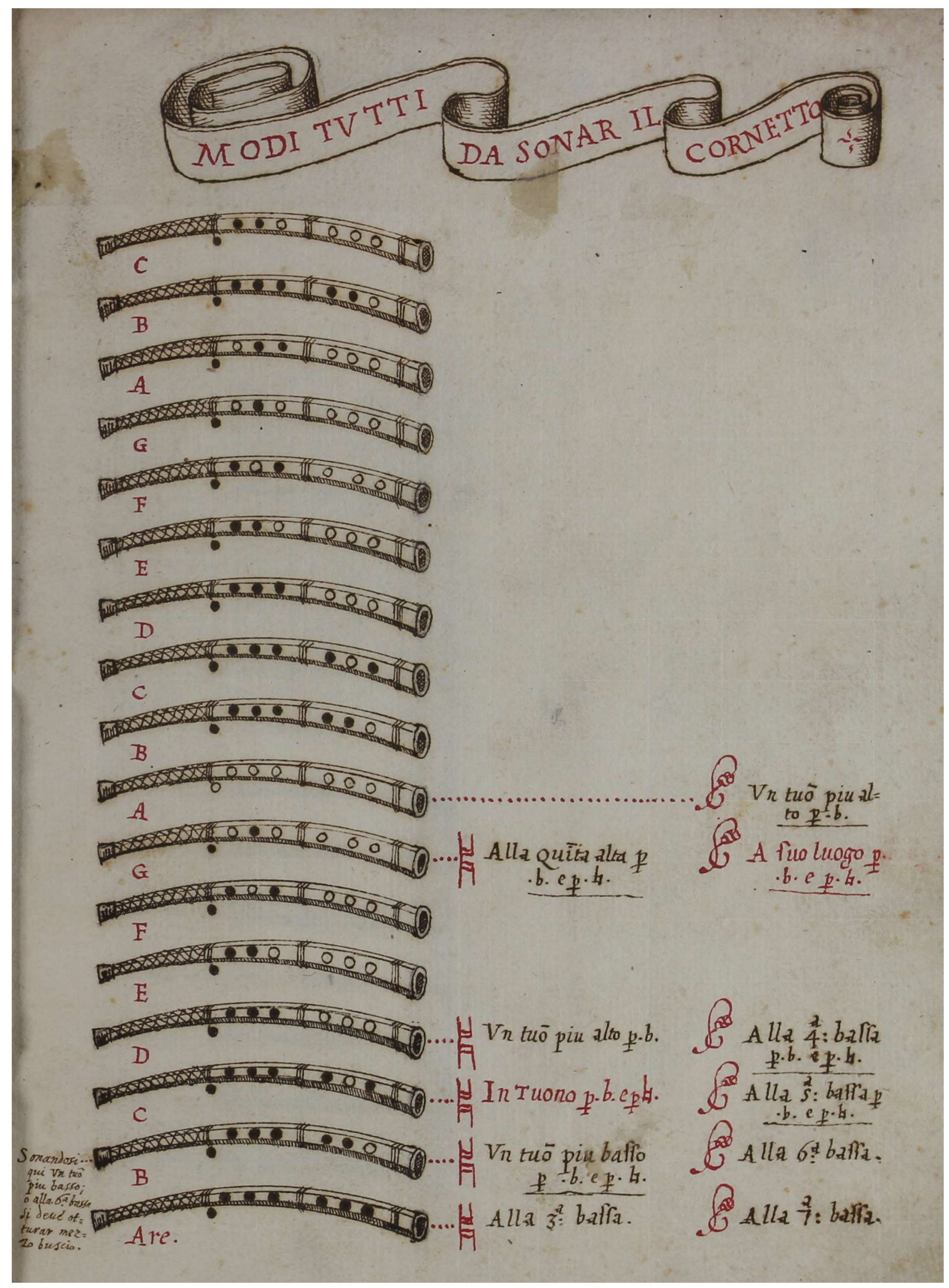

Illus.5: 'Modo tutti da sonar il cornetto,' from Aurelio Virgiliano, Il Dolcimelo (c.1600), Museo internazionale e biblioteca della musica di Bologna, MS C.33, fol.53r. 


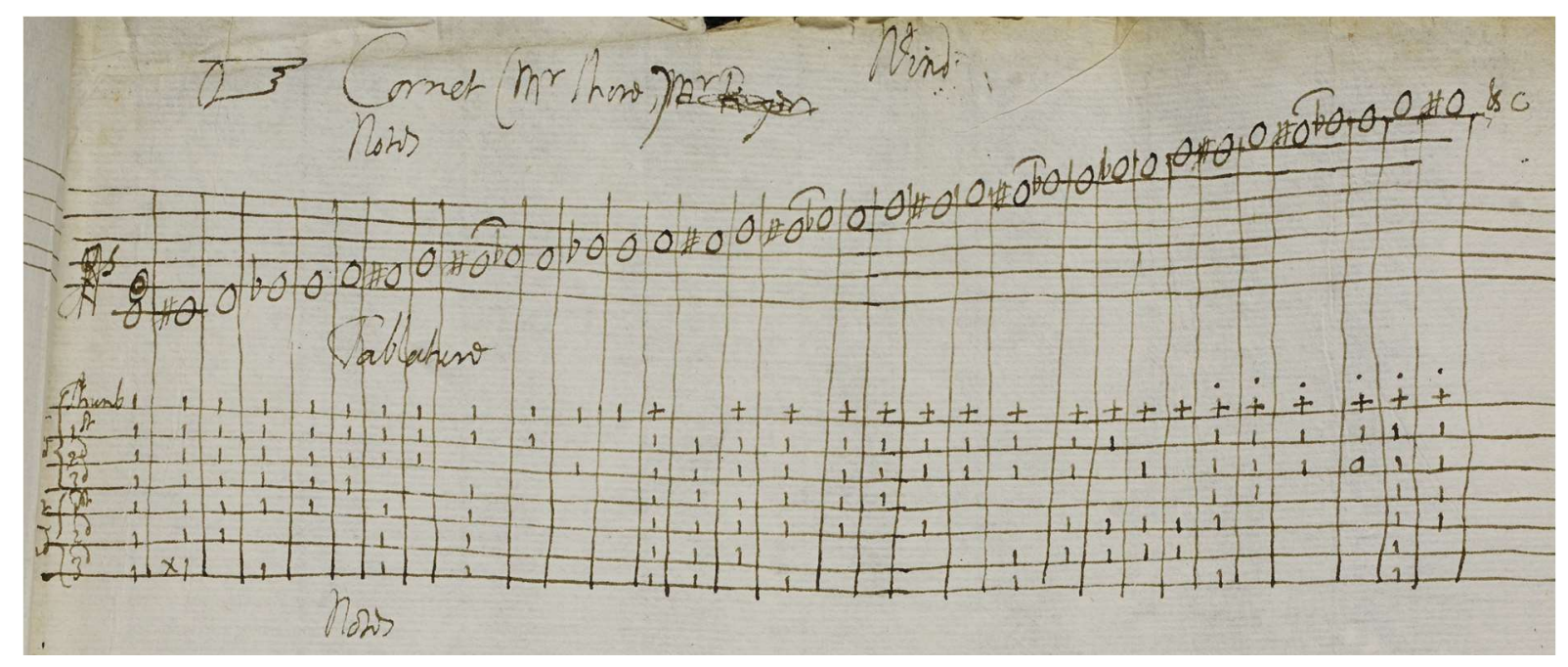

Illus.6: Fingering chart for Mr Shore's cornett, from the James Talbot Manuscript (Oxford, Christ Church Mus. MS 1187), folder 9, fol.7r. 
Canto folo come ita.

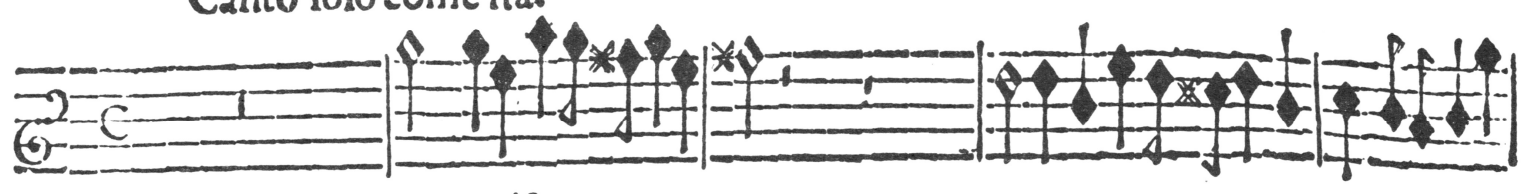

Canzona prima detera la Bonuifia.
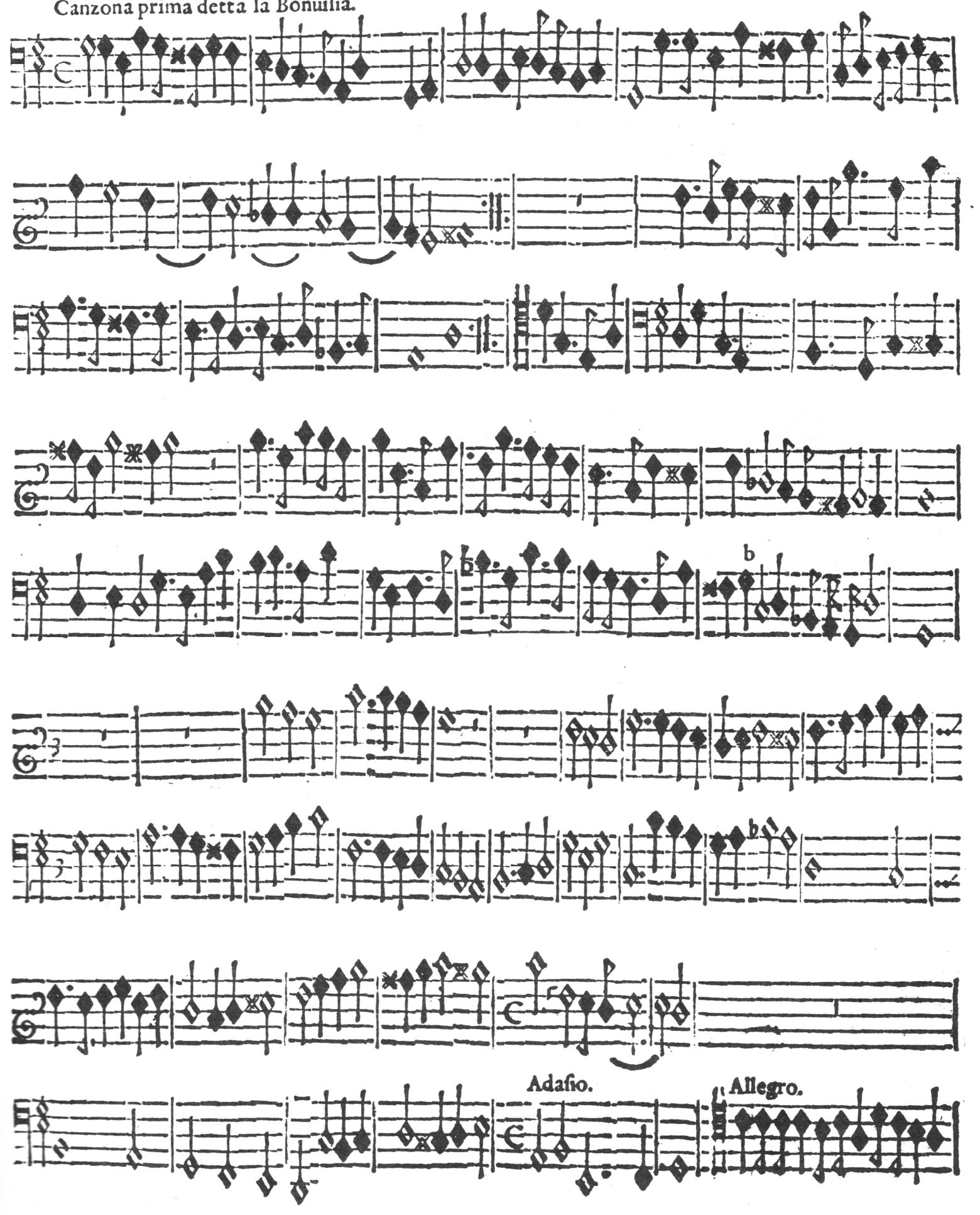

Illus.7: Girolamo Frescobaldi, Canzon prima detta la Bonvisia (extract) from Il primo libro delle canzoni (Rome 1628). 


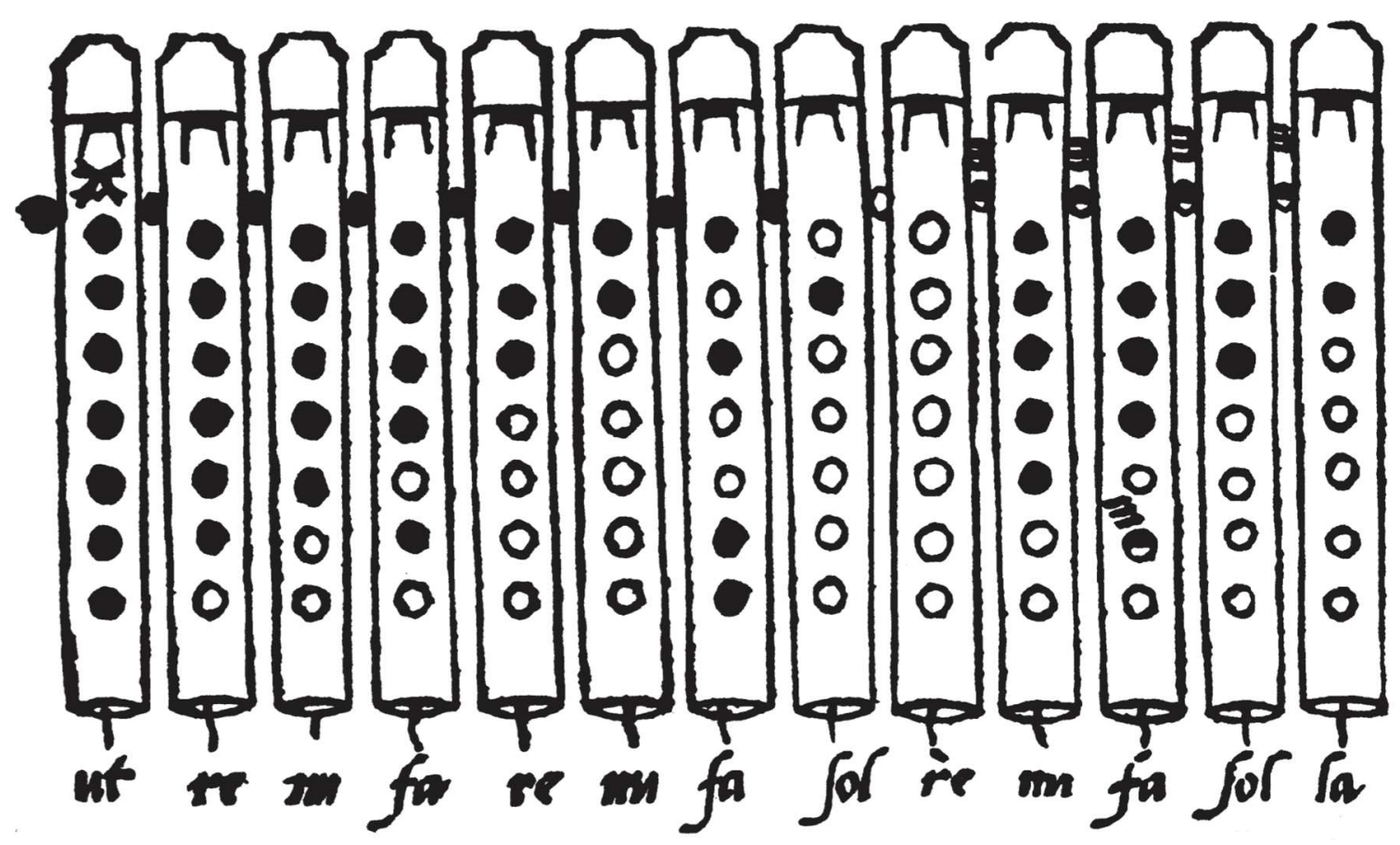

Illus.8: Recorder fingering and solmization syllables, from Silvestro Ganassi, Opera Intitulata Fontegara (Venice, 1535), [p.4: unpaginated].

Audio examples

Performers: Jamie Savan - cornett, Robin Bigwood - organ, Faye Newton - soprano.

Instruments: the cornett is a copy by John McCann of a late 16th-century Venetian cornett, SAM 230, in the musical instrument collection of the Kunsthistorischen Museum, Vienna. The organ is an electronic Hauptwerk instrument, using the Izola sample set made by Sonus Paradisi.

Audio examples $1 \mathrm{a}$ and $1 \mathrm{~b}$ (cornett and organ): Girolamo Frescobaldi, Canzon prima detta la Bonvisia (extract) from Il primo libro delle canzoni (Rome, 1628). Audio ex. 1a is performed at $a^{\prime}=471 \mathrm{~Hz}$; audio ex. $1 \mathrm{~b}$ is performed at $a^{\prime}=395 \mathrm{~Hz}$, with the cornett transposing down a minor third.

Audio example 2 (cornett and organ): Giovanni Paolo Cima, Sonata per cornetto (extract) from Concerti ecclesiatici (Milan, 1610). Performed at $a^{\prime}=471 \mathrm{~Hz}$.

Audio example 3 (soprano and cornett): Johann Walter, two-part canon in primi toni, from Sechs und zwentzig fugen auff die acht Tonos. 